\title{
STUDI EVALUATIF BERBASIS MODEL CSE-UCLA TENTANG PELAKSANAAN PROGRAM PENDIDIKAN BINTARA DI SEKOLAH POLISI NEGARA POLDA BALI
}

\author{
I Gede Putu Semadi, Nyoman Dantes, Ni Made Sri Mertasari \\ Program Studi Penelitian dan Evaluasi Pendidikan, \\ Program Pascasarajana Universitas Pendidikan Ganesha
}

\begin{abstract}
email semadikorsis@gmail.com\{nyoman dantes, ni made sri mertasari \} @pascasarjana.undiksha.ac.id
\end{abstract}

\begin{abstract}
ABSTRAK
Penelitian ini termasuk penelitian evaluatif, yang bertujuan untuk mengevaluasi dan menganalisis Kualitas Pelaksanaan Program Pendidikan Bintara Di Sekolah Polisi Negara Polda Bali dengan model CSA-UCLA System Assesment (A), Program Planning $(P)$, Program Implementation $(P)$, Program Improvement $(P)$, dan Program Certification $(P)$. Responden pada penelitian ini adalah Personil/pegawai Sekolah Polisi Negara Bali (Pendidik danTenaga Kependidikan) 140 orang dan Peserta Didik 92 orang di Sekolah Polisi Negara Polda Bali. Data dikumpulkan dengan menggunakan kuesioner, dokumentasi dan wawancara. Data dianalisis dengan analisis deskriptif kuantitatif dan diverifikasi dengan kuadran Glickman. Hasil penelitian dievaluasi dari dimensi A-P-P-P-P terhadap, 1) Personil/Pegawai SPN Polda Bali (Pendidik dan Tenaga kependidikan) adalah T-R-T-T-T, 2) Peserta Didik yakni T-T-T-R-T dimana $\mathrm{T}$ berarti Tinggi dan $\mathrm{R}$ berarti Rendah, sehingga menunjukkan bahwa secara umum berjalan dengan baik dan berada pada kuadran II yaitu terkategori Baik. Hal ini didukung oleh penilaian yang dilakukan oleh seluruh komponen pendidikan yang ada yaitu Personil/Pegawa SPN Polda Bali (Pendidik dan Tenaga kependidikan) serta Peserta Didik.
\end{abstract}

Kata-kata kunci: CSE-UCLA, Kualitas, Pelaksanaan ABSTRACT

Semadi, I Gede Putu (2019), EVALUATIVE STUDY BASED ON CSE-UCLA MODEL ABOUT IMPLEMENTATION OF THE BINTARA EDUCATION PROGRAM AT THE BALI POLICE REGIONAL POLICE SCHOOL

This thesis has been supervised and approved by the firt supervisor : Prof. Dr. Nyoman Dantes, and the second supervisor : Dr. Ni Made Sri Mertasari, M.Pd.

This research includes evaluative research, which aims to evaluate and analyze the Quality of Implementation of the Bintara Education Program at the Bali Police Regional Police School with CSA-UCLA Model Assessment System (A), Planning Program $(P)$, Implementation Program $(P)$, Improvement Program $(P)$, and Certification Program (P). Respondents in this study were Member of the Bali Police Regional Police School (Educators and Education staff) are 140 people and 92 students at the Bali Police Regional Police School. Data was collected using questionnaires, documentation and interviews. Data were analyzed by quantitative descriptive analysis and verified by Glickman's quadrant. The results of the study were evaluated from the dimensions of A-P-P-P-P to 1) Member of the Bali Police Regional Police School (Educators and Education staff) are T-R-T-T-T, 2) Students are T-T-T$\mathrm{R}-\mathrm{T}$ where $\mathrm{T}$ means High and R means Low, thus indicating that generally it works 
well and is in quadrant II which is categorized Good. This is supported by the assessment carried out by all existing educational components, namely Educators, Education Personnel and Students.

Keywords : CSE-UCLA, Quality, Implementation

\section{PENDAHULUAN}

Pendidikan adalah usaha sadar dan terencana untuk mewujudkan suasana belajar dan proses pembelajaran agar peserta didik secara aktif mengembangkan potensi dirinya untuk memiliki kekuatan spiritual keagamaan, pengendalian diri, kepribadian, kecerdasan, akhlak mulia, serta keterampilan yang diperlukan dirinya, masyarakat, bangsa dan negara hal ini diperkuat dengan Undang - Undang No 20 tahun 2003 tentang Sistem Pendidikan Nasional. Sehingga dalam melaksanakan prinsip penyelenggaraan pendidikan harus sesuai dengan tujuan pendidikan nasional yaitu; mengembangkan kemampuan dan membentuk watak serta peradaban bangsa yang bermartabat dalam rangka mencerdaskan kehidupan bangsa, bertujuan untuk berkembangnya potensi peserta didik agar menjadi manusia yang beriman dan bertakwa kepada Tuhan Yang Maha Esa, berakhlak mulia, sehat, berilmu, cakap, kreatif, mandiri, dan menjadi warga negara yang demokratis serta bertanggung jawab. Negara harus menjamin dan memberikan rasa aman kepada warganya untuk melaksanakan dan mengikuti pendidikan.

Berpedoman pada Peraturan Kapolri (Perkap) No 14 tahun 2015, Polri telah melaksanakan pendidikan secara berjenjang dari pendidikan tingkat bawah sampai paling tinggi yaitu dari pembentukan Tamtama, Bintara, sampai Perwira. Jenis pendidikan dalam Sisdik Polri meliputi: pendidikan akademik, pendidikan manajerial, pendidikan profesi atau vokasi.

Untuk menjadi Polisi khususnya Bintara Polisi yang berkwalitas dan propesional diawali dengan sistem rekrutmen yang baik, bebas dan bersih dari kolusi korupsi dan nepotisme, transparan, akuntabel, humanis berdasarkan Undang-Undang, Peraturan Kapolri, Surat Keputusan Kapolri dan Surat telegram Kapolri atau Telegram Kapolri. Setelah dinyatakan lulus seleksi calon Perserta Didik dididik dimasing masing Lembaga Pendidikan Polri salah satunya Sekolah Polisi Negara (SPN) yang ada di seluruh Indonesia. Dalam Pelaksanaan pendidikan Bintara Polri di Sekolah Polisi Negara Polda Bali menerapkan manajemen Pengelolaan Pendidkan Polri yaitu aspek perencanaan, pengorganisasi, pelaksanaan, pengawasan dan pengendalian (Ren-or-lak-wasdal).

Pendidikan yang diterapkan atau dijalankan oleh suatu Lembaga Pendidikan seperti Lembaga Pendidikan Polri tentu mempunyai kelebihan dan kekurangan namun semuanya dapat kita evaluasi melalui suatu model evaluasi yang disebut dengan Model CSE-UCLA (Center for the study of evaluation University of California in Los Angeles Evaluluation Model). Alasan Model ini sangat cocok digunakan dalam menevaluasi program pendidikan yang diterapkan di SPN Polda Bali. Hal ini sesuai dengan penjelasan dari pakar Suharsimi Arikunto dan Safrudin Abdul Jabar (2006) yaitu model evaluasi UCLA tepat serta cocok digunaan untuk mengevaluasi program pelaksanaan pendidikan di lembaga-lembaga pendidikan khususnya Polri seperti Sekolah Polisi Negara, sehingga sangat tepat digunakan dalam mengevaluasi program pendidikan yang sedang berjalan,disamping itu kelebihan lain yang dimiliki model ini dibandingkan dengan model evaluasi lainnya yaitu adanya tahapan program Implementation yang dapat memperkenalkan keberadaan program yang dievaluasi.

Hal tersebut sangat sesuai dengan pendapat Alkin yaitu model evaluasi UCLA memiliki tahapan program 
Implementation yang dapat memperkenalkan keberadaan program yang dievaluasi dimana tahapan ini tidak memiliki oleh model evaluasi yang lainnya. Untuk mengetahui hasil evaluasi program pendidikan di Sekolah Polisi Negara Polda Bali maka perlu diadakan penelitian dengan menggunakan model evaluasi UCLA terhadap penyelenggaraan system pendidikannya. Menurut Tayibnapis (dalam Divayana 2015) mengemukakan bahwa model CSE-UCLA yang dikembangkan oleh Alkin memiliki lima macam tahapan evaluasi yaitu: Sistem assesment program planning, program implementation, program improvement dan program certification. Sistem assessment yaitu evaluasi yang memberikan informasi tentang keadaan atau posisi sistem. Program Planing yaitu evaluasi yang membantu pemilihan program tertentu yang mungkin akan berhasil memenuhi kebutuhan program. Program Implementation yaitu evaluasi yang menyiapkan informasi apakah program sudah diperkenalkan kepada kelompok tertentu yang tepat seperti yang direncanakan. Program Improvement yaitu evaluasi yang memberikan organisasi, bekerja, atau berjalan, apakah menuju pencapaian tertentu. Program certification yang memberikan tentang nilai atau guna program.

\section{METODE PENELITIAN Tempat Penelitian}

Lokasi penelitian di Sekolah Polisi Negara Polda Bali di jalan Lingga Kelurahan Banyuasri kecamatan Buleleng Kabupaten Buleleng.

Penelitian ini merupakan penelitian evaluatif yang bertujuan untuk mengukur keberhasilan suatu program, produk atau kegiatan tertentu. Penelitian ini diarahkan untuk menilai keberhasilan manfaat, kegunaan, sumbangan dan kelayakan suatu program kegiatan dari suatu unit/lembaga tertentu. Secara epistemologi, dalam pengumpulan data menggunakan pendekatan objektif karena menggunakan Instrument berupa wawancara, dokumentasi, pengamatan dan kuisioner. Penelitian ini akan menggunakan metode penelitian kualitatif dan kuantitatif yang bersifat evaluatif dengan sumber data menggunakan lingkungan Sekolah Polisi Negara Polda Bali membandingkan proses pendidikan Bintara yang ada di lapangan dengan Sistem Pendididkan Polri yang ideal sesuai aturan hukum yang berlaku dan Program pendidikan Tahun Anggaran 2018. Evaluasi proses pembelajaran menggunakan model evaluasi UCLA dengan tahapan program sebagai berikut.

1) sistem asessment,

2) program planning,

3) program implementation,

4) program improvement,

5) progam sertification.

\section{Tabel Rancangan Evaluasi Program CSE - UCLA}

\begin{tabular}{|c|c|}
\hline Dimensi & Indikator \\
\hline 1 & 2 \\
\hline $\begin{array}{c}A \\
\begin{array}{c}\text { (Sistem } \\
\text { Assesment) }\end{array}\end{array}$ & 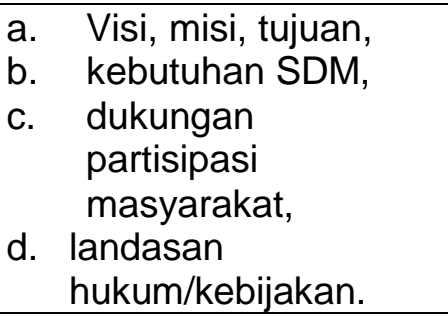 \\
\hline $\begin{array}{c}P \\
\text { (Program } \\
\text { Planning) }\end{array}$ & $\begin{array}{ll}\text { a. } & \text { Struktur Organisasi, } \\
\text { b. } & \text { kesiapan } \\
& \text { kemampuan } \\
& \text { pendidik dan tenaga } \\
& \text { kependidikan, } \\
\text { c. kesiapan } & \text { kemampuan serdik, } \\
\text { d. keuangan, dan } \\
\text { e. sarana } \\
\text { prasarana }\end{array}$ \\
\hline $\begin{array}{c}P \\
\text { (Program } \\
\text { Implementat } \\
\text { ion) }\end{array}$ & 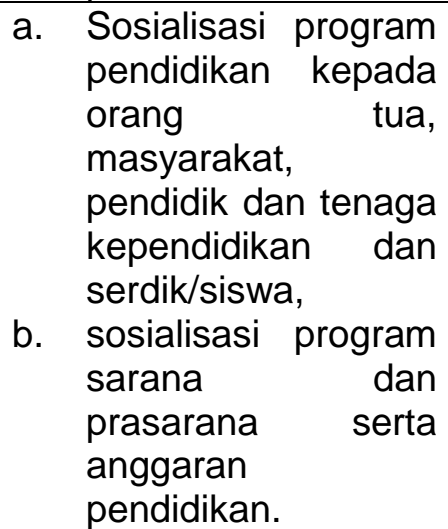 \\
\hline
\end{tabular}




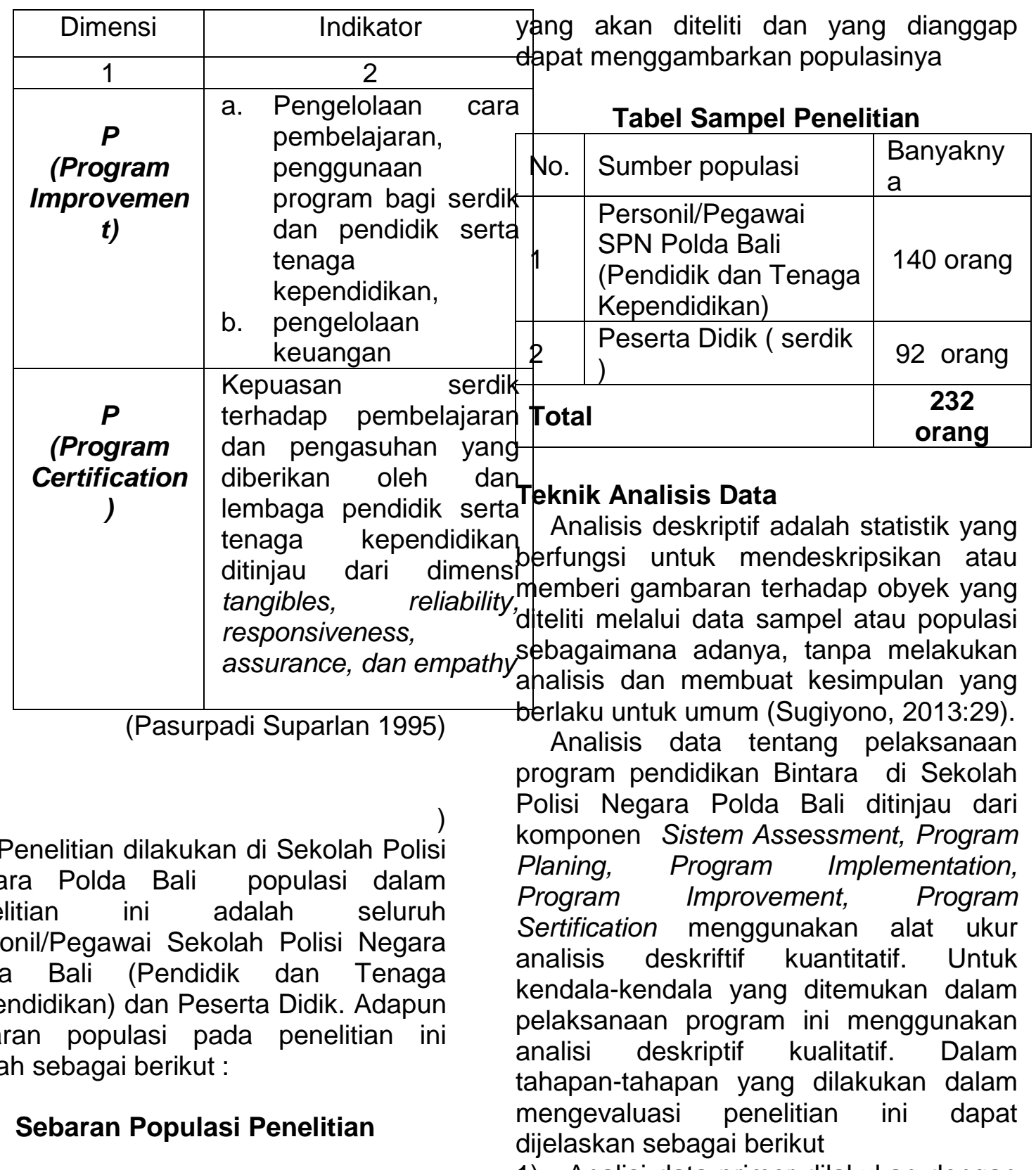

\begin{tabular}{|l|l|c|}
\hline No. & Sumber populasi & Banyaknya \\
\hline 1. & $\begin{array}{l}\text { Personil/Pegawai SPN } \\
\text { Polda Bali (Pendidik dan } \\
\text { Tenaga Kependidikan }\end{array}$ & 170 orang \\
\hline 2. & Peserta Didik & 138 orang \\
\hline \multicolumn{2}{|l|}{ Total } & $\mathbf{3 0 8}$ orang \\
\hline
\end{tabular}

\section{Sampel Penelitian}

Kata sampel juga berasal dari bahasa Inggris yaitu sample yang berarti contoh. Sampel merupakan bagian dari populasi yang menjadi sumber data sebenarnya dari suatu penelitian. Sampel adalah sebagian atau wakil populasi yang diteliti (Arikunto, 2008). Sampel merupakan suatu bagian dari populasi

Analisi data primer dilakukan dengan menganalisi data yang diproleh dari hasil pengisian kuisioner dari pengguna program adalah Personil SPN Polda Bali dan Peserta Didik meliputi :

Menghitung rata-rata skor yang diproleh pada tiap-tiap evaluasi dan mengkonversikan dengan klasifikasi dan katagori dengan menggunakan skala lima berdasarkan rata-rata ideal (Mi) dan standar deviasi ideal (SDi) yaitu Sistem Assessment, Program Planing, Program Implementation, Program Improvement, Program Sertification dengan menggunakan deskriptif kuantitatif dengan criteria 
ideal teoritik (Criterium Ideal Teoretical Reference) yang dikelompokkan menjadi lima katagori pada skala lima. Adapun katagori dan klasifikasi pada skala lima dapat ditunjukkan pada Tabel sebagai berikut :

Tabel pengkatagorian skor ditentukan dengan tiga kategori, yaitu tinggi, sedang, dan rendah. Penentuan dilakukan dengan menghitung Mean ideal (Mi) dan Standar Deviasi ideal (SDi) menggunakan rumus :

$M i=1 / 2$ (nilai maksimal ideal + nilai minimal ideal)

$S D i=1 / 6$ (nilai maksimal ideal - nilai minimal ideal)

Tabel Pengkategorian Skor Tiga

Kategori menggunakan Nilai Ideal

\begin{tabular}{|c|c|}
\hline $\begin{array}{c}\text { Skor } \\
\text { Pengkategori } \\
\text { an skor }\end{array}$ & Keterangan \\
\hline $\begin{array}{c}\mathrm{Mi})<\overline{\mathrm{X}} \leq \\
(\mathrm{Mi}+1,5 \mathrm{SDi})\end{array}$ & Tinggi \\
\hline $\begin{array}{c}(\mathrm{Mi}-1,5 \mathrm{SDi})< \\
\overline{\mathrm{X}} \leq(\mathrm{Mi})\end{array}$ & Cukup \\
\hline$\overline{\mathrm{X}} \leq(\mathrm{Mi}-1,5 \mathrm{SDi})$ & Kurang \\
\hline \multicolumn{2}{|c|}{ Suharsimi Arikunto (2013:263 $)$} \\
\hline
\end{tabular}

b) Menghitung skor yang diproleh kedalam skor baku ( $z$ skor) dengan rumus sebagai berikut :

$$
\begin{aligned}
& \quad \mathrm{z}=\frac{\mathrm{X}-\ddot{\mathrm{X}}}{\mathrm{SD}} \\
& \mathrm{z}=\text { Skor baku } \\
& \mathrm{X}=\text { skor mentah yang diproleh } \\
& \text { reponden } \\
& \ddot{\mathrm{X}}=\text { Rerata/mean } \\
& \mathrm{SD}=\text { simpangan baku/standar } \\
& \quad \text { deviasi }
\end{aligned}
$$

(1)Rerata atau Mean (M) merupakan jumlah nilai kelompok data dibagi dengan jumlah responden dengan rumus sebagai berikut :

$$
\mathrm{Me}=\frac{\sum \mathrm{X}_{\mathrm{i}}}{\mathrm{n}}
$$

Keterangan :

$$
\begin{array}{lll}
\mathrm{Me} & = & \text { Mean (rata-rata) } \\
\sum_{\mathrm{X}} & = & \text { Epsilon (jumlah) } \\
\mathrm{n} & & \text { Nilai } \mathrm{X} \text { ke }-1 \text { sampai ke- } \\
\mathrm{n} & = & \text { Jumlah data }
\end{array}
$$

(2) Simpangan Baku atau Standard Deviation (SD) adalah rata-rata kuadrat penyimpanan masing-masing skor individu dari mean kelompok dengan rumus sebagai berikut :

$$
\begin{aligned}
& \mathrm{S}=\sqrt{\frac{\sum^{\mathrm{f}}(\mathrm{X}-\mu)^{2}}{(\mathrm{n}-1)}} \\
& \text { Keterangan : } \\
& \mathrm{S}=\text { Standard deviasi } \\
& \mathrm{f}=\text { Frekuensi } \\
& \mu=\text { Rerata untuk sampel atau } \\
& \mathrm{X}=\text { populasi } \\
& \mathrm{n}=\quad \text { Banor individual } \\
&
\end{aligned}
$$

atau sebual sampel

c) Mengubah skor baku z kedalam skor $\mathrm{T}$ ( $\mathrm{T}$ skor) dengan rumus :

Skor $T=($ skor $z$ * 10$)+50$

$\mathrm{T}>50$ nilai komponennya tinggi yang disimbolkan dengan $\mathrm{T}$ ( Tinggi )

$\mathrm{T} \leq 50$ nilai komponennya tinggi

\begin{tabular}{|c|c|c|c|c|c|c|c|c|c|}
\hline \multicolumn{5}{|c|}{ Baik } & \multicolumn{5}{|c|}{ Sangat Baik } \\
\hline A & $\mathrm{P}$ & $\mathrm{P}$ & $\mathrm{P}$ & P & A & $P$ & $P$ & $P$ & $P$ \\
\hline $\mathrm{T}$ & $\mathrm{T}$ & $\mathrm{T}$ & $\mathrm{T}$ & $\mathrm{R}$ & $\mathrm{T}$ & $\mathrm{T}$ & $\mathrm{T}$ & $\mathrm{T}$ & $\mathrm{T}$ \\
\hline $\mathrm{T}$ & $\mathrm{T}$ & $\mathrm{T}$ & $\mathrm{R}$ & $\mathrm{T}$ & & & & & \\
\hline $\mathrm{T}$ & $\mathrm{T}$ & $\mathrm{R}$ & $\mathrm{T}$ & $\mathrm{T}$ & & & & & \\
\hline $\mathrm{T}$ & $\mathrm{R}$ & $\mathrm{T}$ & $\mathrm{T}$ & $\mathrm{T}$ & & & & & \\
\hline $\mathrm{R}$ & $\mathrm{T}$ & T & $\mathrm{T}$ & $\mathrm{T}$ & & & & & \\
\hline
\end{tabular}
yang disimbolkan dengan $R$ (Rendah )

Jika 50 adalah bilangan konstanta yang merupakan batas rata-rata kurva normal yang bergerak dari 20 sampai 80 dengan enam nilai standar deviasi dimana satu standar deviasi nilainya adalah 10 .

d) Menginterpretasikan $T$ skor tiap komponen ke dalam katagori tingkat pelaksanaan Kuadran Glickman seperti yang ditunjukkan pada Tabel dibawah ini

Tabel

Tingkat kualitas pelaksanaan Sebuah Program pada semua komponen CSE-UCLA dengan mengikuti Pola Gilckman 
bernilai rendah $(\mathrm{R})$

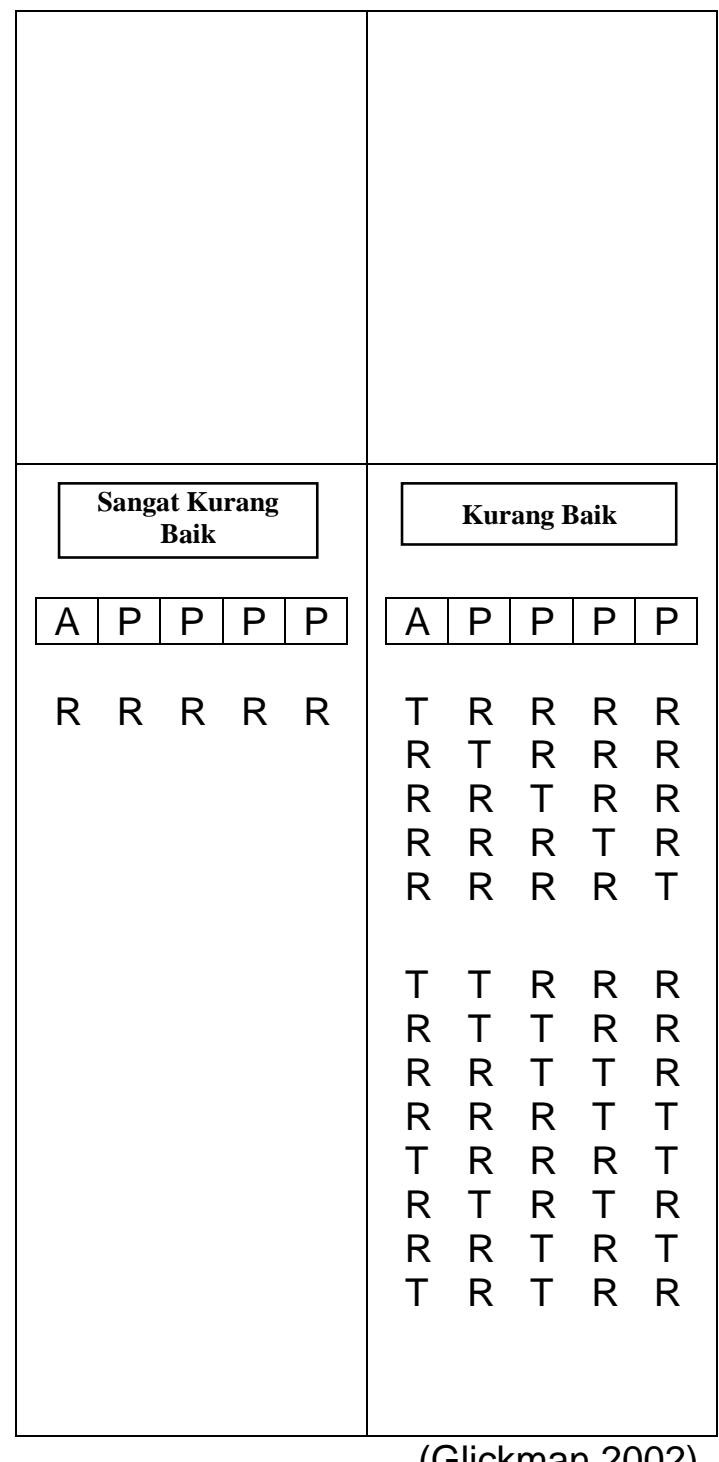

Menurut Glickman (2000), untuk menentukan kualitas sebuah program atau kegiatan ditentukan klasifikasi sebagai berikut.
Sangat baik : Jika kelima komponen/variabel bernilai tinggi $(\mathrm{T})$
Baik : Jika empat dari lima komponen/variabel bernilai tinggi $(\mathrm{T})$
Kurang baik : Jika satu atau dua dari lima komponen/variabel bernilai tinggi $(\mathrm{T})$

$\begin{array}{ll}\text { Sangat } & \text { Jika kelima } \\ \text { kurang baik } & \text { komponen/variabel }\end{array}$

e) Hasil analisis komponen yang diteliti dimaknai perkomponen, antar komponen dan secara secara holistic. Dari analisis ini dapat diproleh suatu gambaran tentang tingkat kualitas Program pendidikan Bintara di Sekolah Polisi Negara Polda Bali dari masing-masing komponen yaitu Sistem Assessment, Program Planing, Program Implementation, Program Improvement, Program Sertification (A-P-P-P-P)

2) Analisis data sekunder dilakukan dengan beberapa tahapan sebagai berikut :

a) Mengkorfimasi hasil tabulasi data primer dengan data yang diproleh melalui tehnik pengumpulan data triangulasi yaitu wawancara, observasi, dan dokumentasi cross chek terhadap tabulasi data yang diproleh.

b) Melakukan pembahasan dan menyimpulkan terhadap hal-hal yang mengakibatkan terjadi gambaran tentang kualitas Program Pendidikan Bintara di Sekolah Polisi Negara Polda Bali di tinjau dari komponen Sistem Assessment, Program Planning, Program Implementation, Program Improvement, Program Sertification (A-P-P-P-P)

Berdasarkan dua tahapan analisis baik dari data primer dan data sekunder dapat diakomodasikan suatu masalah atau kendala yang ada untuk selanjutnya dapat direkomendasikan atternatif solusi atau pemecahannya.

\section{HASIL PENELITIAN DAN \\ PEMBAHASAN \\ Deskripsi Data. \\ Deskripsi data merupakan cara untuk} mengetahui hasil dari penelitian dengan penyajian data yang mudah dipahami sehingga dapat ditarik suatu kesimpulan. Data yang digunakan dalam penelitian ini adalah data primer yang merupakan 
jawaban responden, dimana responden dalam penelitian ini beragam, baik itu wanita-pria, usia yang berbeda, tingkat pendidikan, pangkat dan jabatan dari Personil/Pegawai Sekolah Polisi Negara (SPN) (Pendidik dan Tenaga Kependidikan) serta Peserta Didik yang ada di Sekolah Polisi Negara Polda Bali . Pengumpulan data dilakukan sejak tanggal 10 oktober sampai tanggal 30 oktober 2018. Pendistribusian kuisioner dilakukan dengan cara mengantarkan langsung kuisioner kepada para responden yang menjadi sampel penelitian. Peneliti menetapkan janji untuk pengambilan kuisioner selama 20 hari terhitung sejak kuisioner diantarkan kepada responden atau sesuai dengan kesepakatan yang telah ditetapkan antara responden dan peneliti.

Studi evaluatif ini dilakukan terhadap 140 Personil/Pegawai (Pendidik dan Tenaga Kependidikan) serta 92 responden Peserta Didik yang ada di Sekolah Polisi Negara Polda Bali.

Nilai minimum merupakan nilai terendah dari suatu distribusi data. Pengukuran rata-rata (mean) merupakan cara yang paling umum digunakan untuk mengukur nilai interval dari suatu distribusi data, rata-rata hitung (mean) dari sekelompok atau serangkaian data adalah jumlah dari seluruh nilai data dibagi dengan banyak data. Standar deviasi merupakan perbedaan nilai data yang diteliti dengan rata-rata hitung sekelompok data tersebut. Pada penelitian ini, pengkategorian kualifikasi terhadap satu variabel penelitian yaitu kualitas pendidikan di Sekolah Polisi Negara Polda Bali menggunakan Penilaian Acuan Kriterium (Criterium Reference Evaluation) sebagai berikut :

Tabel Kualifikasi Penilaian Acuan Kriterium

\begin{tabular}{|c|c|}
\hline $\begin{array}{c}\text { Intensitas } \\
\text { Interval Skor }\end{array}$ & Keterangan \\
\hline $90-100$ & Sangat Baik \\
\hline $80-89$ & Baik \\
\hline $65-79$ & Cukup Baik \\
\hline $40-64$ & Kurang Baik \\
\hline $0-39$ & Sangat Kurang Baik \\
\hline
\end{tabular}

(Dantes, 1983)

Pengukuran keberhasilan didasarkan atas penafsiran tingkah laku (performance) yang didasarkan atas kriteria atau standar khusus, artinya derajat penguasaan yang ada didasarkan pada tingkat tertentu yang harus dicapai. Hasil pengukuran dapat menggambarkan derajat baik secara kualitas maupun kuantitas dan eksistensi keterlaksanaan program. Namun hasil pengukuran belum dapat digunakan sebagai acuan pengambilan keputusan dari kualitas dan kuantitas jika belum memiliki pembandingan dengan suatu acuan atau bahan pembanding.

Deskripsi Data kualitas Program Pendidikan Bintara di Sekolah Polisi Negara Polda Bali dimensi AP4 dari penilaian Personil/Pegawai SPN Polda Bali (Pendidik dan Tenaga Kependidikan).

Deskripsi data dalam penelitian ini digunakan untuk menunjukkan besaranbesaran dari tendensi sentral yang meliputi mean, skor minimal, skor maksimal, dan standar deviasi. Hasil analisis deskriptif dapat dilihat pada Tabel di bawah ini :

Tabel Deskripsi Skor kualitas Program Pendidikan Bintara di Sekolah Polisi Negara Polda Bali dimensi AP4 dari penilaian Personil/Pegawai SPN (Pendidik dan Tenaga Kependidikan)

\begin{tabular}{|c|c|c|c|c|c|c|c|}
\hline \multirow[b]{2}{*}{$\begin{array}{l}\mathbf{N} \\
\mathbf{0}\end{array}$} & \multirow{2}{*}{$\begin{array}{c}\text { Hasil } \\
\text { Perhitu } \\
\text { ngan }\end{array}$} & \multicolumn{5}{|c|}{ Dimensi } & \multirow{2}{*}{$\begin{array}{l}\text { Implem } \\
\text { entasi } \\
\text { (AP4) }\end{array}$} \\
\hline & & $\mathbf{A}$ & $\mathbf{P}$ & $\mathbf{P}$ & $\mathbf{P}$ & $\mathbf{P}$ & \\
\hline 1 & $\sum X$ & 71 & 97 & 35 & 48 & 13 & 38288 \\
\hline & & 12 & 16 & 40 & 55 & $\begin{array}{c}06 \\
5\end{array}$ & \\
\hline 2 & $\mathrm{~N}$ & $\begin{array}{c}14 \\
0\end{array}$ & $\begin{array}{c}14 \\
0\end{array}$ & $\begin{array}{c}14 \\
0\end{array}$ & $\begin{array}{c}14 \\
0\end{array}$ & $\begin{array}{c}14 \\
0\end{array}$ & 140 \\
\hline 3 & $\mathrm{Me}$ & $\begin{array}{l}50, \\
80\end{array}$ & $\begin{array}{l}69, \\
40\end{array}$ & $\begin{array}{l}25, \\
29\end{array}$ & $\begin{array}{l}34, \\
68\end{array}$ & $\begin{array}{l}93, \\
32\end{array}$ & - \\
\hline 4 & SD & $\begin{array}{c}6,1 \\
3\end{array}$ & $\begin{array}{c}5,4 \\
6\end{array}$ & $\begin{array}{c}2,5 \\
4\end{array}$ & $\begin{array}{c}3,0 \\
9\end{array}$ & $\begin{array}{c}5,6 \\
2\end{array}$ & - \\
\hline 5 & Mo & $\begin{array}{l}50, \\
80\end{array}$ & $\begin{array}{l}69, \\
40\end{array}$ & $\begin{array}{l}25, \\
29\end{array}$ & $\begin{array}{l}34, \\
68\end{array}$ & $\begin{array}{l}93, \\
32\end{array}$ & 273,49 \\
\hline
\end{tabular}




\begin{tabular}{|c|c|c|c|c|c|c|}
\hline 6 & SMi & 49 & $\begin{array}{c}39, \\
5\end{array}$ & 15 & 20 & 92 \\
\hline 7 & Mo (\%) & $\begin{array}{l}78, \\
15\end{array}$ & $\begin{array}{l}86, \\
75\end{array}$ & $\begin{array}{l}84, \\
29\end{array}$ & $\begin{array}{l}86, \\
70\end{array}$ & $\begin{array}{l}88, \\
88\end{array}$ \\
\hline 8 & Max & 62 & 79 & 30 & 40 & $\begin{array}{c}10 \\
4\end{array}$ \\
\hline 9 & Min & 36 & 53 & 19 & 29 & 80 \\
\hline 1 & katagor & $\mathrm{Cu}$ & Bai & Bai & Bai & Bai \\
\hline 0 & & $\begin{array}{c}\mathrm{ku} \\
\mathrm{p} \\
\text { bai } \\
\mathrm{k}\end{array}$ & $\mathrm{k}$ & $\mathrm{k}$ & $\mathrm{k}$ & $\mathrm{k}$ \\
\hline
\end{tabular}

Keterangan :

$\begin{array}{ll}\sum_{N} X & : \text { Total skor } \\ \text { SMi } & : \text { Jumlah responden } \\ \text { Me } & : \text { Skor maksimum ideal } \\ \text { Mo } & : \text { Mean variabel } \\ \text { Mo (\%) } & : \text { Mean persentil } \\ \text { Max } & : \text { Nilai Maksimum } \\ \text { Min } & : \text { Nilai Minimum } \\ \text { SD } & : \text { Standar Deviasi }\end{array}$

Berdasarkan tabel di atas, adapun histogram yang diajukan adalah sebagai berikut :

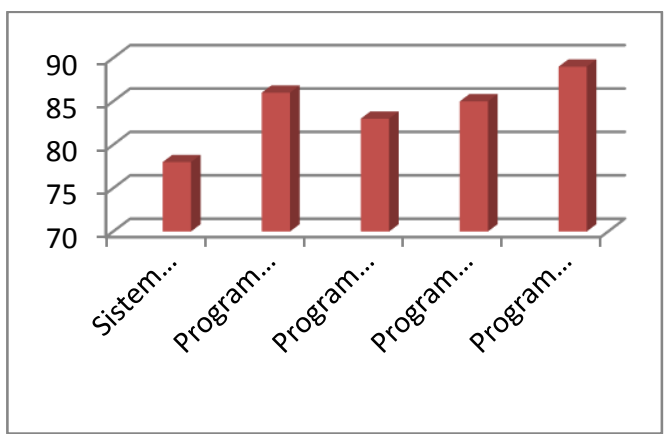

Grafik : Poligram kualitas Program Pendidikan Bintara di Sekolah Polisi Negara Polda Bali dimensi AP4 dari penilaian Personil/Pegawai SPN (Pendidik dan Tenaga Kependidikan)

Dari data diatas dapat disimpulkan secara univariat bahwa kualitas Program Pendidikan Bintara di Sekolah Polisi Negara Polda Bali dimensi AP4 dari penilaian Personil/Pegawai SPN Polda Bali (Pendidik dan Tenaga Kependidikan) dilihat dari dimensi Sistem Assesment terkategori cukup baik, dimensi Program Planning terkategori baik, dimensi 213,5gram Implementation terkategori baik, dimensi Program Improvement 84, 9 sategori baik dan dimensi Program Certification terkategori baik. Jadi secara umum kualitas Program Pendidikan Bintara di Sekolah Polisi Negara Polda Bali dimensi AP4 dari penilaian Personil/Pegawai Sekolah Polisi Negara Polda Bali (Pendidik dan Tenaga Kependidikan) adalah Baik.

Deskripsi Data kualitas Program Pendidikan Bintara di Sekolah Polisi Negara Polda Bali dimensi AP4 dari penilaian Peserta Didik (Serdik)

Deskripsi data dalam penelitian ini digunakan untuk menunjukkan besaranbesaran dari tendensi sentral yang meliputi mean, skor minimal, skor maksimal, dan standar deviasi. Hasil analisis deskriptif dapat dilihat pada Tabel di bawah ini :

Tabel Deskripsi Skor kualitas Program Pendidikan Bintara di Sekolah Polisi Negara Polda Bali dimensi AP4 dari Peserta Didik (serdik)

\begin{tabular}{|c|c|c|c|c|c|c|c|}
\hline \multirow[b]{2}{*}{$\begin{array}{l}\mathbf{N} \\
0\end{array}$} & \multirow[b]{2}{*}{$\begin{array}{c}\text { Hasil } \\
\text { Perhitu } \\
\text { ngan }\end{array}$} & \multicolumn{5}{|c|}{ Dimensi } & \multirow[b]{2}{*}{$\begin{array}{c}\text { Impl } \\
\text { eme } \\
\text { ntas } \\
\text { i } \\
\text { (AP } \\
4 \text { ) }\end{array}$} \\
\hline & & A & $\mathbf{P}$ & $\mathbf{P}$ & $\mathbf{P}$ & $\mathbf{P}$ & \\
\hline 1 & $\sum X$ & $\begin{array}{l}53 \\
23\end{array}$ & $\begin{array}{l}65 \\
88\end{array}$ & $\begin{array}{l}24 \\
40\end{array}$ & $\begin{array}{l}32 \\
52\end{array}$ & $\begin{array}{l}86 \\
58\end{array}$ & $\begin{array}{c}2626 \\
1\end{array}$ \\
\hline 2 & $\mathrm{~N}$ & 92 & 92 & 92 & 92 & 92 & 92 \\
\hline 3 & $\mathrm{Me}$ & $\begin{array}{l}57 . \\
86\end{array}$ & $\begin{array}{l}71 . \\
61\end{array}$ & $\begin{array}{l}26 . \\
52\end{array}$ & $\begin{array}{l}35 . \\
35\end{array}$ & $\begin{array}{l}94 . \\
11\end{array}$ & - \\
\hline 4 & SD & $\begin{array}{c}3.3 \\
3\end{array}$ & $\begin{array}{c}3.6 \\
7\end{array}$ & $\begin{array}{c}1.9 \\
9\end{array}$ & $\begin{array}{c}2.7 \\
0\end{array}$ & $\begin{array}{c}5.2 \\
6\end{array}$ & - \\
\hline 5 & Mo & $\begin{array}{l}57 . \\
86\end{array}$ & $\begin{array}{l}71 . \\
61\end{array}$ & $\begin{array}{l}26 . \\
52\end{array}$ & $\begin{array}{l}35 . \\
35\end{array}$ & $\begin{array}{l}94 . \\
11\end{array}$ & $\begin{array}{c}285 . \\
45\end{array}$ \\
\hline 6 & SMi & 58 & 71 & 25 & 35 & 95 & $\begin{array}{c}282 . \\
50\end{array}$ \\
\hline 7 & Mo (\%) & $\begin{array}{c}89 . \\
01\end{array}$ & $\begin{array}{c}89 . \\
51\end{array}$ & $\begin{array}{l}88 . \\
41\end{array}$ & $\begin{array}{l}88 . \\
37\end{array}$ & $\begin{array}{l}89 . \\
63\end{array}$ & $\begin{array}{c}88.9 \\
9 \%\end{array}$ \\
\hline 8 & Max & 64 & 79 & 30 & 40 & $\begin{array}{c}10 \\
5\end{array}$ & - \\
\hline 9 & Min & 51 & 62 & 20 & 29 & 85 & - \\
\hline
\end{tabular}




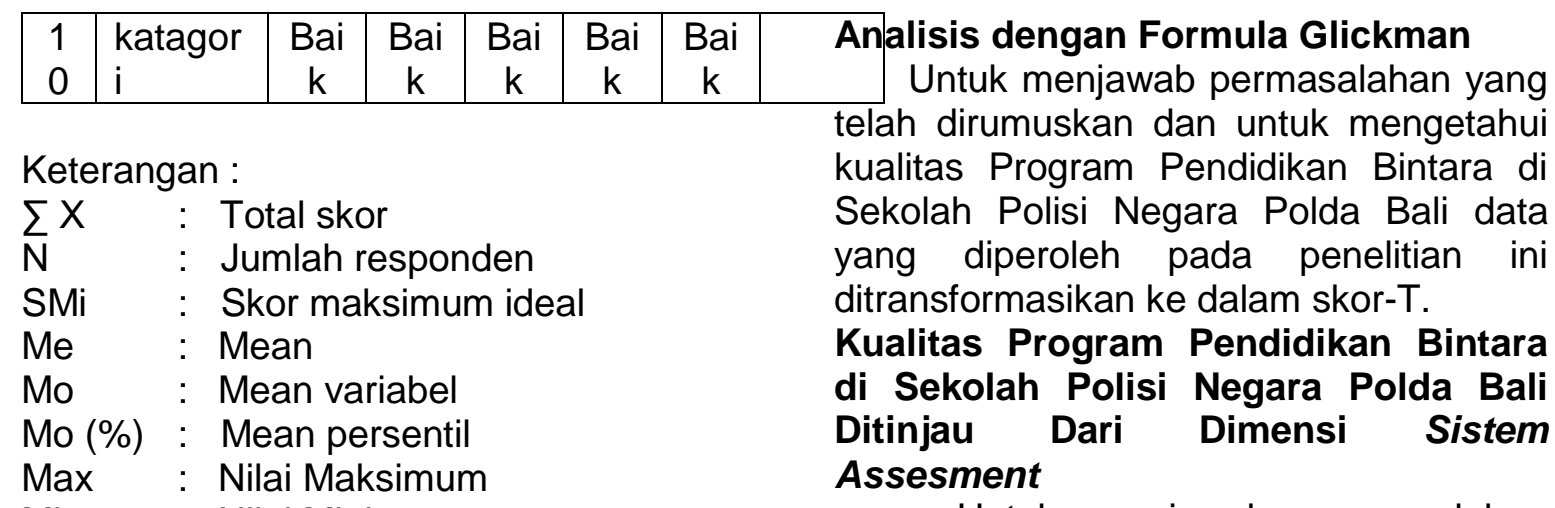

Min : Nilai Minimum

SD : Standar Deviasi

Berdasarkan tabel di atas, adapun histogram yang diajukan adalah sebagai berikut:

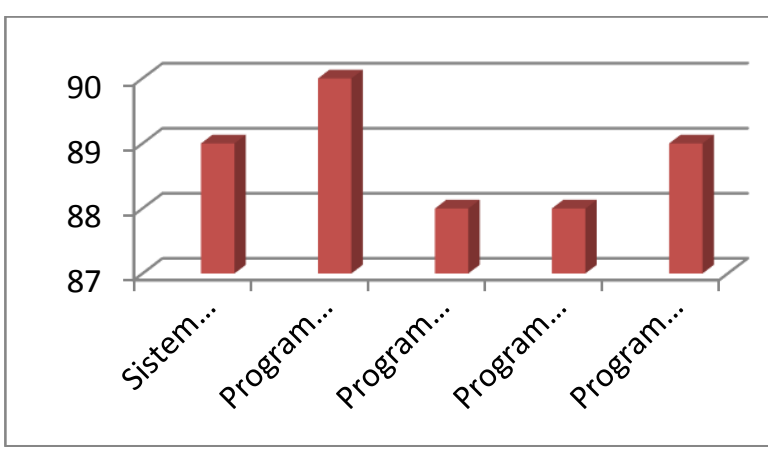

\section{Grafik 4.1.3 Poligram kualitas Program Pendidikan Bintara di Sekolah Polisi Negara Polda Bali dimensi AP4 dari Peserta Didik (serdik)}

Dari data diatas dapat disimpulkan secara univariat bahwa kualitas Program Pendidikan Bintara di Sekolah Polisi Negara Polda Bali dimensi AP4 dari penilaian tenaga kependidikan dilihat dari dimensi Sistem Assesment terkategori cukup baik, dimensi Program Planning terkategori baik, dimensi Program Implementation terkategori baik, dimensi Program Improvement terkategori baik dan dimensi Program Certification terkategori baik. Jadi secara umum kualitas Program Pendidikan Bintara di Sekolah Polisi Negara Polda Bali dimensi AP4 dari penilaian Peserta Didik (serdik) adalah Baik.
Untuk menjawab permasalahan yang dirumuskan pada rumusan masalah nomor satu yaitu untuk mengetahui kualitas pelaksanaan program ditinjau dari dimensi sistem assesment, yang meliputi :

a. visi, misi, tujuan,

b. kebutuhan sumber daya manusia,

c. dukungan partisipasi masyarakat,

d. landasan hukum/kebijakan.

\section{Kualitas Program Pendidikan Bintara di Sekolah Polisi Negara Polda Bali Ditinjau Dari Dimensi Program Planning}

Untuk menjawab permasalahan yang dirumuskan pada rumusan masalah nomor dua yaitu untuk mengetahui kualitas pelaksanaan program ditinjau dari dimensi sistem Planning, yang meliputi ;

a. Struktur Organisasi,

b. Kesiapan kemampuan pendidik dan tenaga kependidikan,

c. Kesiapan kemampuan serdik,

d. Sarana prasaran,

e. Anggaran atau keuangan.

\section{Kualitas Program Pendidikan Bintara di Sekolah Polisi Negara Polda Bali Ditinjau Dari Dimensi Program Implementation}

Untuk menjawab permasalahan yang dirumuskan pada rumusan masalah nomor tiga yaitu untuk mengetahui kualitas pelaksanaan program ditinjau dari dimensi Program Implementation, yaitu yang memberikan informasi tentang

a. Sosialisasi program pendidikan kepada masyarakat/orang tua serdik, 
b. sosialisasi program pendidikan kepada pengguna program yaitu pendidik dan tenaga kependidikan serta serdik,

c. sosialisasi sarana prasarana dan anggaran pendidikan

\section{Kualitas Program Pendidikan Bintara di Sekolah Polisi Negara Polda Bali Ditinjau Dari Dimensi Program Improvement}

Untuk menjawab permasalahan yang dirumuskan pada rumusan masalah nomor empat yaitu untuk mengetahui kualitas pelaksanaan program ditinjau dari dimensi Program Improvement yaitu yang memberikan informasi tentang :

a. bagaimana pengelolaan cara pembelajaran pendidik,

b. bagaimana penggunaan program bagi pendidik dan tenaga kependidikan serta serdik,

c. bagaimana pengelolaan anggaran atau keuangan.

\section{Kualitas Program Pendidikan Bintara di Sekolah Polisi Negara Polda Bali Ditinjau Dari Dimensi Program Sertification}

Untuk menjawab permasalahan yang dirumuskan pada rumusan masalah nomor lima yaitu untuk mengetahui kualitas pelaksanaan program ditinjau dari dimensi Program Sertification sebagai berikut ;

a. tangibles (bukti fisik),

b. reliability (kehandalan),

c. responsiveness (ketanggapan),

d. empathy (perhatian) dan,

e. assurance (kepastian/jaminan)

\section{Program Pendidikan Bintara di Sekolah Polisi Negara Polda Bali ditinjau dari Model CSE - UCLA}

Berdasarkan deskripsi data di atas, data hasil penelitian dapat dirangkum sebagai tabel berikut :
Tabel Rangkuman Hasil Kualitas Pelaksanaan Program Pendidikan Bintara di Sekolah Polisi Negara Polda Bali untuk Personil/Pegawai SPN (Pendidik dan Tenaga Kependidikan) Ditinjau dari Model Evaluasi CSE - UCLA

\begin{tabular}{|c|c|c|c|c|c|}
\hline \multirow{2}{*}{$\mathrm{N}$} & & \multicolumn{3}{|c|}{ Frekuensi } & \\
\cline { 3 - 5 } 0 & Dimensi & $\begin{array}{c}\text { Tin } \\
\text { ggi }\end{array}$ & $\begin{array}{c}\text { Ren } \\
\text { dah }\end{array}$ & Hasil & Ket \\
\hline 1 & $\begin{array}{c}\text { Sistem } \\
\text { Assesment (A) }\end{array}$ & 78 & 62 & $\begin{array}{c}\text { Ting } \\
\text { gi }\end{array}$ & $\mathrm{T}$ \\
\hline 2 & $\begin{array}{c}\text { Program } \\
\text { Planning (P) }\end{array}$ & 69 & 71 & $\begin{array}{c}\text { Ting } \\
\text { gi }\end{array}$ & $\mathrm{R}$ \\
\hline 3 & $\begin{array}{c}\text { Program } \\
\text { Implementatio } \\
\text { n (P) }\end{array}$ & 76 & 64 & $\begin{array}{c}\text { Ting } \\
\text { gi }\end{array}$ & $\mathrm{T}$ \\
\hline 4 & $\begin{array}{c}\text { Program } \\
\text { Improvement } \\
\text { (P) }\end{array}$ & 77 & 63 & $\begin{array}{c}\text { Ting } \\
\text { gi }\end{array}$ & $\mathrm{T}$ \\
\hline 5 & $\begin{array}{c}\text { Program } \\
\text { Certification } \\
(\mathrm{P})\end{array}$ & 71 & 69 & $\begin{array}{c}\text { Ting } \\
\text { gi }\end{array}$ & $\mathrm{T}$ \\
\hline
\end{tabular}

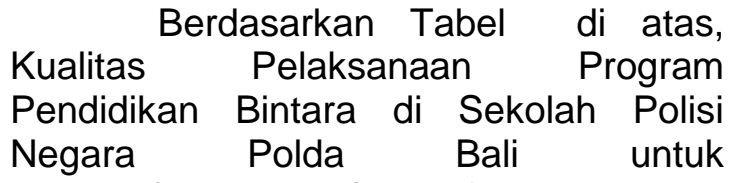
Personil/Pegawai SPN (Pendidik dan Tenaga Kependidikan) adalah terkategori Baik

Tabel 4.2 Pengkategorian Skor Tiga Kategori menggunakan Nilai Ideal

\begin{tabular}{|c|c|}
\hline $\begin{array}{c}\text { Skor } \\
\text { Pengkategorian } \\
\text { skor }\end{array}$ & Keterangan \\
\hline$(\mathrm{Mi})<\overline{\mathrm{X}} \leq(\mathrm{Mi}+1,5 \mathrm{SDi})$ & Tinggi \\
\hline$(\mathrm{Mi}-1,5 \mathrm{SDi})<\overline{\mathrm{X}} \leq(\mathrm{Mi})$ & Cukup \\
\hline$\overline{\mathrm{X}} \leq(\mathrm{Mi}-1,5 \mathrm{SDi})$ & Kurang \\
\hline
\end{tabular}

Suharsimi Arikunto ( $2013: 263$ )

Sebagai pembanding untuk mengetahui Nilai Ideal berdasarkan Tabel di atas dilihat dari dimensi :

a. Sistem Assessment (A) : 
$M i=1 / 2$ (nilai maksimal ideal + nilai minimal ideal)

$\mathrm{Mi}=1 / 2(62+36)$

$=49$

$S D i=1 / 6$ (nilai maksimal ideal - nilai minimal ideal)

$\mathrm{SDi}=1 / 6(62-36)$

$$
=4,42
$$

Hasil perhitungan mean ideal (Mi) dan standar deviasi ideal (Sdi) dimasukkan dalam Tabel, maka kecendrungan Nlai Ideal akan sebagai berikut.

$49-55,63=$ Tinggi

42,37-49= Cukup

$\leq 42,37=$ kurang

Dari perhitungan diproleh mean sistem Assesment (A) sebesar $\mathbf{5 0 , 8 0}$ Jika dimasukkan dalam Tabel maka harga mean tersebut kedalam kriteria tinggi. Sehingga disimpulkan Nilai Ideal kualitas Program Pendidikan Bintara di Sekolah Polisi Negara Polda Bali dimensi Sistem Assesment (A) dari penilaian Personil/Pegawai SPN (Pendidik dan Tenaga Kependidikan) masuk kedalam kategori tinggi.

b. Program Planning $(P)$ :

$M i=1 / 2$ (nilai maksimal ideal + nilai minimal ideal)

$\mathrm{Mi}=1 / 2(79+53)$

$=66$

$S D i=1 / 6$ (nilai maksimal ideal - nilai minimal ideal)

$\mathrm{SDi}=1 / 6(79-53)$

$$
=4,42
$$

Hasil perhitungan mean ideal (Mi) dan standar deviasi ideal (Sdi) dimasukkan dalam Tabel 4.2 maka kecendrungan nilai akan sebagai berikut.

$66-72,63=$ Tinggi

$59,37-66=$ Cukup

$\leq 59,37=$ Kurang

Dari perhitungan diproleh mean

Program Planning (P) sebesar 69,40 Jika dimasukkan dalam Tabel, maka harga mean tersebut kedalam kriteria tinggi. Sehingga disimpulkan Nilai Ideal kualitas Program Pendidikan Bintara di Sekolah Polisi Negara Polda Bali dimensi Program Planning (P) dari penilaian Personil/Pegawai SPN (Pendidik dan Tenaga Kependidikan) masuk kedalam kategori tinggi.

c. Program Implementation $(P)$ :
$M i=1 / 2$ (nilai maksimal ideal + nilai minimal ideal)

$\mathrm{Mi}=1 / 2(30+19)$

$=24,5$

$S D i=1 / 6$ (nilai maksimal ideal - nilai minimal ideal)

$\mathrm{SDi}=1 / 6(30-19)$

$=1,87$

Hasil perhitungan mean ideal (Mi)

dan standar deviasi ideal (SDi) dimasukkan dalam Tabel 4.2 maka kecendrungan nilai akan sebagai berikut.

$24,5-27.30=$ Tinggi

$21,69-24,5=$ Cukup

$\leq 21,69=$ Kurang

Dari perhitungan diproleh mean Program Implementation $(\mathrm{P})$ sebesar 25,29 Jika dimasukkan dalam Tabel, maka harga mean tersebut kedalam kriteria tinggi. Sehingga disimpulkan Nilai Ideal kualitas Program Pendidikan Bintara di Sekolah Polisi Negara Polda Bali dimensi Program Implementation $(\mathrm{P})$ dari penilaian Personil/Pegawai SPN (Pendidik dan Tenaga Kependidikan) masuk kedalam kategori tinggi.

d. Program Improvement $(P)$ :

$M i=1 / 2$ (nilai maksimal ideal + nilai minimal ideal)

$\mathrm{Mi}=1 / 2(40+29)$

$=34,5$

$S D i=1 / 6$ (nilai maksimal ideal - nilai minimal ideal)

$\mathrm{SDi}=1 / 6(40-29)$

$$
=1,87
$$

Hasil perhitungan mean ideal (Mi) dan standar deviasi ideal (SDi) dimasukkan dalam Tabel 4.2 maka kecendrungan nilai akan sebagai berikut.

$34,5-37.30=$ Tinggi

$31,69-34,5=$ Cukup

$\leq 31,69=$ Kurang

Dari perhitungan diproleh mean Program Improvement $(\mathrm{P})$ sebesar $\mathbf{3 4 , 5 0}$ Jika dimasukkan dalam Tabel maka harga mean tersebut kedalam kriteria tinggi. Sehingga disimpulkan Nilai Ideal kualitas Program Pendidikan Bintara di Sekolah Polisi Negara Polda Bali dimensi Program Improvement $(\mathrm{P})$ dari penilaian Personil/Pegawai SPN (Pendidik dan Tenaga Kependidikan) masuk kedalam kategori tinggi.

e. Program Sertification $(P)$ : 
$M i=1 / 2$ (nilai maksimal ideal + nilai minimal ideal)

$\mathrm{Mi}=1 / 2(104+80)$

$=92$

$S D i=1 / 6$ (nilai maksimal ideal - nilai minimal ideal)

$\mathrm{SDi}=1 / 6(104-80)$

$=4,08$

Hasil perhitungan mean ideal (Mi) dan standar deviasi ideal (SDi) dimasukkan dalam Tabel 4.2 maka kecendrungan nilai akan sebagai berikut.

$92-98,12=$ Tinggi

$85,88-92=$ Cukup

$\leq 85,88=$ Kurang

Dari perhitungan diproleh mean Program

Sertification (P) sebesar 93,32 Jika dimasukkan dalam Tabel, maka harga mean tersebut kedalam kriteria tinggi. Sehingga disimpulkan Nilai Ideal kualitas Program Pendidikan Bintara di Sekolah Polisi Negara Polda Bali dimensi Program Sertification (P) dari penilaian Personil/Pegawai SPN (Pendidik dan Tenaga Kependidikan) masuk kedalam kategori tinggi.

Jadi Nilai Ideal kualitas Program Pendidikan Bintara di Sekolah Polisi Negara Polda Bali dimensi AP4 dari penilaian Personil/Pegawai SPN (Pendidik dan Tenaga Kependidikan) adalah terkatagori tinggi.

Tabel Rangkuman Hasil kualitas Pelaksanaan Program Pendidikan Bintara di Sekolah Polisi Negara Polda Bal untuk Peserta Didik Ditinjau dari Model Evaluasi CSE - UCLA

\begin{tabular}{|c|c|c|c|c|c|}
\hline \multirow[b]{2}{*}{$\begin{array}{l}N \\
0\end{array}$} & \multirow[b]{2}{*}{ Dimensi } & \multicolumn{3}{|c|}{ Frekuensi } & \multirow[b]{2}{*}{ Ket } \\
\hline & & $\begin{array}{l}\text { Tin } \\
\text { ggi }\end{array}$ & $\begin{array}{l}\text { Ren } \\
\text { dah }\end{array}$ & $\begin{array}{l}\mathrm{Ha} \\
\text { sil }\end{array}$ & \\
\hline 1 & $\begin{array}{c}\text { Sistem } \\
\text { Assesme } \\
n t(\mathrm{~A})\end{array}$ & 47 & 45 & $\begin{array}{l}\text { Tin } \\
\text { ggi }\end{array}$ & $T$ \\
\hline 2 & $\begin{array}{l}\text { Program } \\
\text { Planning } \\
\text { (P) }\end{array}$ & 51 & 41 & $\begin{array}{l}\text { Tin } \\
\text { ggi }\end{array}$ & $T$ \\
\hline 3 & $\begin{array}{l}\text { Program } \\
\text { Impleme } \\
\text { ntation } \\
\text { (P) }\end{array}$ & 48 & 44 & $\begin{array}{l}\text { Tin } \\
\text { ggi }\end{array}$ & $T$ \\
\hline 4 & $\begin{array}{l}\text { Program } \\
\text { Improve } \\
\text { ment }(\mathrm{P})\end{array}$ & 44 & 48 & $\begin{array}{l}\text { Re } \\
\text { nd } \\
\text { ah }\end{array}$ & $\mathrm{R}$ \\
\hline 5 & $\begin{array}{c}\text { Program } \\
\text { Certificati } \\
\text { on }(\mathrm{P})\end{array}$ & 47 & 45 & $\begin{array}{l}\text { Tin } \\
\text { ggi }\end{array}$ & $T$ \\
\hline
\end{tabular}

Berdasarkan Tabel di atas, Kualitas Pelaksanaan Program Pendidikan Bintara di Sekolah Polisi Negara Polda Bali untuk Peserta Didik terkategori Baik.

Deskripsi Nilai Ideal kualitas Program Pendidikan Bintara di Sekolah Polisi Negara Polda Bali dimensi AP4 dari penilaian Peserta Didik. Penetuan Kriteria Nilai Ideal menggunakan mean ideal (Mi) dan standar deviasi ideal (SDi) dilihat dari dimensi :

a. Sistem Assessment (A) :

$M i=1 / 2$ (nilai maksimal ideal + nilai minimal ideal)

$\mathrm{Mi}=1 / 2(64+51)$

$=57,5$

$S D i=1 / 6$ (nilai maksimal ideal - nilai minimal ideal)

$\mathrm{SDi}=1 / 6(64-51)$

$$
=2,21
$$

Hasil perhitungan mean ideal (Mi) dan standar deviasi ideal (SDi) dimasukkan dalam Tabel 4.2 maka kecendrungan nilai akan sebagai berikut.

$57,5-60,81=$ Tinggi

$54,18-57,50=$ Cukup

$\leq 54,18=$ Kurang

Dari perhitungan diproleh mean Sistem Assessment (A) sebesar $\mathbf{5 7 , 8 6}$ Jika 
dimasukkan dalam Tabel maka harga mean tersebut kedalam kriteria tinggi. Sehingga disimpulkan Nlai Ideal kualitas Program Pendidikan Bintara di Sekolah Polisi Negara Polda Bali dimensi Sistem Assesment (A) dari penilaian Peserta Didik masuk kedalam kategori tinggi.

\section{b. Program Planning $(P)$ :}

$M i=1 / 2($ nilai maksimal ideal + nilai minimal ideal)

$\mathrm{Mi}=1 / 2(79+62)$

$=70,50$

$S D i=1 / 6$ (nilai maksimal ideal - nilai minimal ideal)

$\mathrm{SDi}=1 / 6(79-62)$

$$
=2,89
$$

Hasil perhitungan mean ideal (Mi) dan standar deviasi ideal (SDi) dimasukkan dalam Tabel 4.2 maka kecendrungan nilai akan sebagai berikut.

$70,81-74,83=$ Tinggi

$66,16-70,81=$ Cukup

$\leq 66,16=$ kurang

Dari perhitungan diproleh mean Program Planning $(P)$ sebesar 71,61 Jika dimasukkan dalam Tabel maka harga mean tersebut kedalam kriteria tinggi. Sehingga disimpulkan Nilai Ideal kualitas Program Pendidikan Bintara di Sekolah Polisi Negara Polda Bali dimensi Program Planning $(\mathrm{P})$ dari penilaian Peserta Didik masuk kedalam kategori tinggi.

c. Program Implementation $(P)$ :

$M i=1 / 2$ (nilai maksimal ideal + nilai minimal ideal)

$$
\begin{aligned}
\mathrm{Mi} & =1 / 2(30+20) \\
& =25
\end{aligned}
$$

$S D i=1 / 6$ (nilai maksimal ideal - nilai minimal ideal)

$\mathrm{SDi}=1 / 6(30-20)$

$$
=1,70
$$

Hasil perhitungan mean ideal (Mi) dan standar deviasi ideal (SDi) dimasukkan dalam Tabel 4.2 maka kecendrungan nilai akan sebagai berikut.

$25-27,55=$ Tinggi

22,45-25= Cukup

$\leq 22,45=$ Kurang

Dari perhitungan diproleh mean Program Implementation (P) sebesar 26,52 Jika dimasukkan dalam Tabel maka harga mean tersebut kedalam kriteria tinggi. Sehingga disimpulkan Nlai Ideal kualitas Program Pendidikan Bintara di Sekolah Polisi Negara Polda Bali dimensi Program Implementation (P) dari penilaian Peserta Didik (Serdik) masuk kedalam kategori tinggi.

d. Program Improvement $(P)$ :

$M i=1 / 2$ (nilai maksimal ideal + nilai minimal ideal)

$\mathrm{Mi}=1 / 2(40+29)$

$=34,5$

$S D i=1 / 6$ (nilai maksimal ideal - nilai minimal ideal)

$\mathrm{SDi}=1 / 6(40-29)$

$$
=1,87
$$

Hasil perhitungan mean ideal (Mi) dan standar deviasi ideal (SDi) dimasukkan dalam Tabel 4.2 maka kecendrungan nilai akan sebagai berikut.

$34,5-37,30=$ Tinggi

$31,69-34,5=$ Cukup

$\leq 31,69=$ Kurang

Dari perhitungan diproleh mean Program Improvement $(\mathrm{P})$ sebesar 35,35 Jika dimasukkan dalam Tabel maka harga mean tersebut kedalam kriteria tinggi. Sehingga disimpulkan Nilai Ideal kualitas Program Pendidikan Bintara di Sekolah Polisi Negara Polda Bali dimensi Program Improvement $(\mathrm{P})$ dari penilaian Peserta Didik masuk kedalam kategori tinggi.

e. Program Sertification $(P)$ :

$M i=1 / 2$ (nilai maksimal ideal + nilai minimal ideal)

$\mathrm{Mi}=1 / 2(105+85)$

$=95$

$S D i=1 / 6$ (nilai maksimal ideal - nilai

minimal ideal)

$\mathrm{SDi}=1 / 6(105-85)$

$$
=3,4
$$

Hasil perhitungan mean ideal (Mi) dan standar deviasi ideal (SDi) dimasukkan dalam Tabel 4.2 maka kecendrungan nilai akan sebagai berikut.

94,05-100.1 = Tinggi

89,90-95 = Cukup

$\leq 89,90=$ Kurang

Dari perhitungan diproleh mean Program Sertification (P) sebesar 94,11 Jika dimasukkan dalam Tabel, maka harga mean tersebut kedalam kriteria tinggi. Sehingga disimpulkan Nila Ideal kualitas Program Pendidikan Bintara di Sekolah Polisi Negara Polda Bali dimensi Program 
Sertification (P) dari penilaian Peserta Didik masuk kedalam kategori tinggi.

\section{Pembahasan}

Setiap organisasi mempunyai tujuan baik tujuan umum maupun khusus, jangka pendek maupun jangka panjang, yang akan direalisasikan dengan menggunakan berbagai sumberdaya atau faktor produksi yang ada. Pengelola tidak akan dapat mencapai tujuan secara optimal bilamana penggunaan sumberdaya atau faktor produksi dilakukan tidak dengan proses yang benar. Manajemen memegang peranan sangat penting, sebab manajemen merupakan "proses perencanaan, pengorganisasian, pemimpinan dan pengendalian upaya organisasi dan proses penggunaan semua sumberdaya organisasi untuk tercapainya tujuan organisasi yang telah ditetapkan" (Stoner, 1994: Efektivitas berbicara tentang visi dan arah, berhubungan dengan memfokuskan energi organisasi pada arah tertentu (Veitzhal Rivai, 2003: 147).

Sistem pendidikan Polri secara umum berjalan dengan baik dan lancar sesuai dengan delapan standar pendidikan Polri yang telah diatur dalam Perkap No 14 tahun 2015. Dari standar kompetensi lulusan dan standar isi serta standar proses sudah ditentukan oleh Lembaga Pendidikan Polri, satuan pendidikan Polri dalam implementasinya akan sama diseluruh jajaran Polri baik itu pada Pusat Pendidikan Polri (Pusdik) dan Sekolah Polisi Negara (SPN). Yang membedakan antara masing-masing satuan pendidikan adalah pelaksanaan dukungan Sumber Daya Manusia.

\section{Hasil penelitian terhadap Pelaksanaan Program Pendidikan Bintara di Sekolah Polisi Negara Polda Bali dengan responden Personil/Pegawai (Pendidik dan Tenaga Kkependidikan) dengan hasil sebagai berikut :}

a. Kualitas Pelaksanaan Program Pendidikan Bintara di Sekolah Polisi Negara Polda Bali ditinjau dari dimensi Sistem Assesment memberikan hasil yang Tinggi $(\mathrm{T})$. b. Kualitas Pelaksanaan Program Pendidikan Bintara di Sekolah Polisi Negara Polda Bali ditinjau dari dimensi Program Planning memberikan hasil yang Rendah $(R)$.

c. Kualitas Pelaksanaan Program Pendidikan Bintara di Sekolah Polisi Negara Polda Bali ditinjau dari dimensi Program Implementation memberikan hasil yang Tinggi $(T)$.

d. Kualitas Pelaksanaan Program Pendidikan Bintara di Sekolah Polisi Negara Polda Bali ditinjau dari dimensi Program Improvement memberikan hasil yang Tinggi ( $\mathrm{T}$ ).

e. Kualitas Pelaksanaan Program Pendidikan Bintara di Sekolah Polisi Negara Polda Bali ditinjau dari dimensi Program Certification memberikan hasil yang Tinggi $(\mathrm{T})$.

Deskripsi Nilai Ideal kualitas Program Pendidikan Bintara di Sekolah Polisi Negara Polda Bali dimensi AP4 dari penilaian Personil/Pegawai SPN (Pendidik dan Tenaga Kependidikan) dilihat dari dimensi :

a. Sistem Assesment (A) :

Kualitas Program Pendidikan Bintara di Sekolah Polisi Negara Polda Bali penilaian Personil/Pegawai SPN (Pendidik dan Tenaga Kependidikan) masuk kedalam kategori Tinggi.

b. Program Planning $(P)$ :

Kualitas Program Pendidikan Bintara di Sekolah Polisi Negara Polda Bali penilaian Personil/Pegawai SPN (Pendidik dan Tenaga Kependidikan) masuk kedalam kategori Tinggi.

c. Program Implementation $(P)$ :

Kualitas Program Pendidikan Bintara di Sekolah Polisi Negara Polda Bali penilaian Personil/Pegawai SPN (Pendidik dan Tenaga Kependidikan) masuk kedalam kategori Tinggi.

d. Program Improvement $(P)$ :

Kualitas Program Pendidikan Bintara di Sekolah Polisi Negara Polda Bali penilaian Personil/Pegawai SPN (Pendidik dan Tenaga Kependidikan) masuk kedalam kategori Tinggi.

e. Program Sertification $(P)$ : 
Kualitas Program Pendidikan Bintara di Sekolah Polisi Negara Polda Bali penilaian Personil/Pegawai SPN (Pendidik dan Tenaga Kependidikan) masuk kedalam kategori Tinggi.

Jadi kualitas Program Pendidikan Bintara di Sekolah Polisi Negara Polda Bali dimensi AP4 dari penilaian Personil/Pegawai SPN (Pendidik dan Tenaga Kependidikan) berdasarkan kriteria Nilai Ideal adalah terkatagori Tinggi

\section{Hasil penelitian terhadap Pelaksanaan Program Pendidikan Bintara di Sekolah Polisi Negara Polda Bali dengan responden Peserta didik dengan hasil sebagai berikut :}

a. Kualitas Pelaksanaan Program Pendidikan Bintara di Sekolah Polisi Negara Polda Bali ditinjau dari dimensi Sistem Assesment memberikan hasil yang Tinggi ( $\mathrm{T}$ ).

b. Kualitas Pelaksanaan Program Pendidikan Bintara di Sekolah Polisi Negara Polda Bali ditinjau dari dimensi Program Planning memberikan hasil yang Tinggi ( $\mathrm{T})$.

c. Kualitas Pelaksanaan Program Pendidikan Bintara di Sekolah Polisi Negara Polda Bali ditinjau dari dimensi Program Implementation memberikan hasil yang Tinggi $(T)$.

d. Kualitas Pelaksanaan Program Pendidikan Bintara di Sekolah Polisi Negara Polda Bali ditinjau dari dimensi Program Improvement memberikan hasil yang Rendah $(R)$.

e. Kualitas Pelaksanaan Program Pendidikan Bintara di Sekolah Polisi Negara Polda Bali ditinjau dari dimensi Program Certification memberikan hasil yang Tinggi $(T)$.

Deskripsi Nilai Ideal kualitas Program Pendidikan Bintara di Sekolah Polisi Negara Polda Bali dimensi AP4 dari penilaian Peserta Didik dilihat dari dimensi :

a. Sistem Assesment (A) :

Kualitas Program Pendidikan Bintara di Sekolah Polisi Negara Polda Bali penilaian Personil/Pegawai SPN
Peserta Didik masuk kedalam kategori Tinggi.

b. Program Planning $(P)$ :

Kualitas Program Pendidikan Bintara di Sekolah Polisi Negara Polda Bali penilaian Personil/Pegawai SPN Peserta Didik masuk kedalam kategori Tinggi.

c. Program Implementation $(P)$ :

Kualitas Program Pendidikan Bintara di Sekolah Polisi Negara Polda Bali penilaian Personil/Pegawai SPN Peserta Didik masuk kedalam kategori Tinggi.

d. Program Improvement $(P)$ :

Kualitas Program Pendidikan Bintara di Sekolah Polisi Negara Polda Bali penilaian Personil/Pegawai SPN Peserta Didik masuk kedalam kategori Tinggi.

e. Program Sertification $(P)$ :

Kualitas Program Pendidikan Bintara di Sekolah Polisi Negara Polda Bali penilaian Personil/Pegawai SPN Peserta Didik masuk kedalam kategori Tinggi.

Jadi kualitas Program Pendidikan Bintara di Sekolah Polisi Negara Polda Bali dimensi AP4 dari penilaian Peserta Didik berdasarkan kriteria Nilai Ideal adalah terkatagori Tinggi

\section{Simpulan.}

Kualitas Pelaksanaan Program Pendidikan Bintara di Sekolah Polisi Negara Polda Bali ditinjau dari dimensi Sistem Asessment, Program Planning, Program Implementation, Program Improvement, program sertification (A-PP-P-P) dari analisis formula Glickman dan Nilai Ideal adalah terkatagori baik dan tinggi, sesuai kuesioner dan wawancara yang dilakukan di terhadap beberapa responden Personil/Pegawai SPN (Tenaga Kependidikan dan Pendidik) serta Peserta Didik, namum program pendidikan ini masih ada kendala dan permasalahan yang perlu diperbaiki dan ditingkatkan.

\section{Rekomendasi.}

Dari implikasi di atas maka dapat direkomendasikan hal-hal sebagai berikut 
1) Agar Kepala Sekolah Polisi Negara Polda Bali membuat perencanaan yang lebih baik untuk menyusun kelompok kerja (pokja) yang bertujuan untuk menyusun visi, misi dan tujuan serta kebijakan atau landasan hukum Program Pendidikan dan memerintahkan staf bawahanya unuk bertugas mensosialisasikan kepada seluruh personil baik pendidik dan tenaga kependidikan sehingga dapat dipahami dan dilaksanakan dalam peyelenggaraan program pendidikan di Sekolah Polisi Negara Polda Bali;

2) Dalam menentukan kebutuhan Sumber Daya Manusia, Kepala Sekolah Polisi Negara Polda Bali memprioritaskan personil/Pegawai Polri yang mempunyai kualifikasi akademis yang berpendidikan serendah-rendahnya Diploma tiga dan Strata satu (S1) terutama sebagai Pendidik (gadik dan pengasuh).

3) Sosialisasi Program Pendidikan Bintara di Sekolah Polisi Negara Polda Bali perlu dilaksanakan secara berkesinambungan terhadap masyarakat, orang tua peserta didik dan Peserta Didik sehingga mereka paham dan mengerti tentang penyelenggaraan Pendidikan yang dilaksanakan oleh Polri.

4) Tingginya kepuasan Peserta Didik terhadap pelayanan yang diberikan oleh Lembaga, Pendidik dan Tenaga Kependidikan menunjukkan bahwa kinerja mereka yang bertugas di lembaga ini dinilai baik dan Peserta Didik menginginkan lembaga ini kedepannya kualitas pelayanan lebih baik dengan sekarang dan dapat mendukung ekonomi masyarakat sekitarnya. $\mathrm{Hal}$ ini bisa menjadi pertimbangan Pimpinan pada pola kebijakan penyelenggaraan pendidikan dimasa depan.

\section{Daftar Pustaka}

Arikunto $S$ dan Abdul Jabar Cepi Safruddin (2006) Evaluasi
Program 'Pendidikan

Pedoman Praktis bagi Praktisi

Pendidikan, Jakarta, Indonesi, PT Bumi Aksara.

Arikunto S (2016) Dasar-Dasar Evaluasi Pendidikan edisi 2, Jakarta, Indonesi, PT Bumi Aksara.

Agung Slamet Kusmanto, Dwi Yuwono Puji Sugiharto, Sugiyo (2014) The Development of Evaluation Program Model Guidance and Counseling Service Based on CSE-UCLA of Juniro High School in Kudus, Journal of Educational Research and Evaluation Prodi Penelitian dan Evaluasi Pendidikan, Program Pascasarjana, Universitas Negeri Semarang

Adriani Siska (2015), Evaluasi CSE UCLA pada Studi Proses Pembelajaran Matematika pada SMP Negeri Satu Atap Lerek, Tahun Pembelajaran 2015. Jurnal Pendidikan Matematika IAIN Raden Intan Lampung 6(2),

Ahmad Calam ( 2016) Merumuskan Visi dan Misi Lembaga Pendidikan, jurnal saintikon program studi sistem informasi STMIK Triguma Dharma. Diunduh tanggal 28 Januari 20018)

Alex Aldha Yudi (2012) Pengembangan Mutu Pendidikan Ditinjau dari Segi Sarana dan Prasarana Jurnal cerdas sifa FIK UNP Padang. Diunduh tanggal 28 Januari 20018)

Banu Caesar firmansah dan Emma Julianti (2014) Pengaruh Kredibilitas Merek Terhadap Niat Beli Dengan Mediasi Kualitas yang Dirasa Komsumen Produk Batik Jetis Di Sidoharjo. Journal of 
Business and Bangking STIE Perbanas Surabaya.

Dewi Ratna (2016) Kebijakan Pendidikan Di Tinjau Dari Segi Hukum Kebijakan Publik, Jurnal IImu Hukum Bagian Hukum Administrasi Negara, Fakultas Hukum Universitas Jambi. Diunduh tanggal 28 Januari 20018)

Divayana Dewa Hendra (2016), Evaluasi Program Sertifikasi Komputer Pada Universitas Teknologi Indonesia Menggunakan Model CSE-UCLA, Tahun Pelajaran 2016. Desertasi Jurusan Pendidikan Teknik Informatika, Fakultas Teknik dan Kejuruan Universitas Pendidikan Ganesha Singaraja, Indonesia.

Fathorrahman (2017) Kompetensi Pedagogik, Profesional, Kepribadian Dan Kompetensi Sosial dosen di Sekolah Tinggi Ilmu Ekonomi ASIA Malang jurnal Akademika Vol. 15. No.1 Februari 2017

Humancapitaljournal.com tentang 5 pengetian sumber daya manuasia menurut para ahli diunduh tanggal 28 januari 2018 )

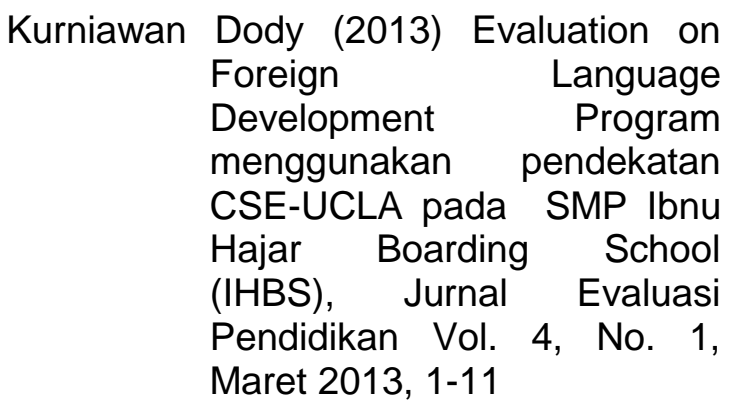

